\title{
Pengaruh motivasi kerja terhadap produktivitas karyawan di komaneka resorts, komanekabisma ubud
}

\author{
Ni Made Dwi Parwati ${ }^{1)}$, Anak Agung Putri Sri ${ }^{2}$, Ni Putu Ratna Sari ${ }^{3)}$ \\ Program Studi Diploma IV Pariwisata, Fakultas Pariwisata, Universitas Udayana ${ }^{123)}$ \\ JL. DR. R.Goris No. 07, Denpasar, Kode Pos : 80232, Telp/Fax : 0361-223798 \\ E-mail:fakultaspariwisata_unud@yahoo.com \\ E-mail : mddwiparwati@gmail.com ${ }^{1}$,
}

\begin{abstract}
Abstrak
Karya wan merupakan sumber daya manu sia sebagai pelaku yang men unjang terc apain ya tu juan . Sumber daya manusia dikatakan produktif apabila dapat menyelesaikan tugas d an tanggung jawab te pat waktu. Salah satu faktor yang mempengaruhi produktivitas adalah motivasi kerja. Pen elitian ini memilih lokasi di Komaneka Bisma dikarenakan persentase okupansi kamar di Komaneka Bisma pada tahun 2019 mengalami fluktuatif a pabila dilihat dari bulan februari sa mpai mei di ta hun 2019 dibandingkan dengan tahun 2018. Tujuan penelitia n ini untuk mengetahui pengaruh motivasi kerja terhadap produktivitas karyawan dan untuk mengetahui seberapa besar motivasi kerja memberikan pengaruh terhadap produktivitas k arya wan di Koma neka Resorts, Komaneka Bisma.

Teknik penentuan sampelyang digunakan menggunakan sampling jenuh den gan 112 kuesioner kepada seluruh karyawan operasionaldi Komaneka Bisma Ubud. Pengumpu lan data melalu i observasi, wawancara, studi kepustakaan, dan dokumentasi. Analisis data yaitu uji validitas, uji reliabilitas, uji normalitas, analisis regresi linier sederhana, hipotesis (ujit), dan koefisien determinasi dengan menggunakan bantuan SPSS for Windows versi 23.0. Hasil penelitian menunjukkan variabel motivasi kerja secara parsial mempengaruhi produktivitas karyawan di Komaneka Bisma Ubud. Hasil uji determinasi menunjukkan bahwa nilai $\mathrm{R}^{2}$ sebesar $46 \%$ variabel motivasi kerja. Ujit pada variabel motivasi kerja $(\mathrm{X})$, menunjukan bahwa nila i $\mathrm{t}_{\text {-hitung }}$ dengan nilai 9,688 lebih besar daripada $\mathrm{t}_{\text {-tabel }}$ dengan nilai 1.981 serta nila i sign if ik an si v a riabe $1 \mathrm{X}$ sebesar 0,000 lebih kecil daripada nilai signifikansi alpha sebesar 0,025 , bahwa hip ote sis $\mathrm{H}_{0}$ ditola $\mathrm{k}$ dan variabel motivasikerja $(\mathrm{X})$ memiliki pengaruh positif yang signifikan terhadap produktivitas karya wan dan layakmenjadi variabel penentu produktivitas karyawan. Hasil uji koefisien determinasi menunjukkan bahwa nilai $\mathrm{R}^{2}$ sebesar $46 \%$ variabel motivasi kerja.
\end{abstract}

Kata kunci : Motivasi Kerja, Karyawan, Produktivitas, Analisis Regresi Linear Sederhana, Komaneka Resorts

\begin{abstract}
Human resources are said to be productive if they can complete tasks and responsibilities on time. One factor that affects productivity is work motivation. This research was conducted at Komaneka Bisma be cause the percentage of room occupancy in Komaneka Bisma in 2019 experienced fluctuations viewed from Feb ruary to May in 2019 compared to 2018. The purpose of this research was to determine the effect of work motivation on employee productivity and to find outhow much work motivation has an influence on employee productivity at Komaneka Resorts, Komaneka Bisma. The sampling technique used was sa turated sa mpling with 112 questionnaires to all operational employees at Komaneka Bisma Ubud. Da ta collection through observation, interviews, litera ture study, and documentation. Data analy sis a re the validity te st, reliability test, normality test, simple linear regression analysis, hypothesis $\left(\mathrm{t}_{\text {-test }}\right)$, and the coefficient of determination using SPSS for Windows version 23.0. The results of Determination test show the value of R2 is $46 \%$ the variable work motivation. T-test on work motivation variable $(\mathrm{X})$, shows that the value of $\mathrm{t}$-count with a value of 9,688 is greater thant-table with a value of 1,981 and the significance value of variable $X$ is 0,000 smaller than the significance value of a lpha of 0,025 , that the hypothesis $\mathrm{H}_{0}$ is rejected and the variable work motivation $(\mathrm{X})$ has a significant positive effect on employee productivity and deserves to be a determining varia ble in employee productivity. The coefficient of determination test results indicate that the $\mathrm{R} 2$ value of $46 \%$ the variable work motivation
\end{abstract}

Keywords: Work Motivation, Productivity, Employee, Simple Linear Regression Analysis, Komaneka Resorts 


\section{PENDAHULUAN}

Berdasarkan pada Undang-undang Nomor 10 Tahun 2009 tentang Kepariwisataan, pengertian Pariwisata adalah "berbagai macam kegiatan wisata dan didukung berbagai fasilitas serta layanan yang disediakan oleh masyarakat, pengusaha, pemerintah, dan pemerintah daerah". Sedangkan yang dimaksud dengan Kepariwisataan adalah "seluruh kegiatan yang terkait dengan pariwisata dan bersifat multidimensi serta multi disiplin yang muncul sebagai wujud kebutuhan setiap orang dan negara serta interaksi antar wisatawan dan masyarakat setempat, sesama wisatawan, pemerintah, pemerintah daerah, dan pengusaha". Bali merupakan daerah tujuan wisata yang terkenal di dunia, yang sekaligus membawa nama harum negara Indonesia di dunia internasional. Potensi obyek wisata dikenal dengan konsep 4A yang terdiri dari atraksi, amenitas, aksesibilitas, dan fasilitas pendukung tambahan (anciliary).

Atraksi wisata mencakup daya tarik alam, budaya, maupun buatan/ artificial. Amenitas wisata merupakan fasilitas-fasilitas dasar pendukung yang berada di obyek wisata yang ditujukan untuk memberikan pelayanan kepada wisatawan, seperti restoran, tempat ibadah, toko-toko souvenir dan cinderamata, bank, tempat penukaran uang, kator informasi wisata, fasilitas kesehatan, dan fasilitas keamanan. Aksesibilitas wisata merupakan sarana yang memberikan kemudahan kepada wisatawan untuk mencapai daerah tujuan wisata meliputi, denah perjalanan wisata, data atraksi wisata, bandara, transportasi darat, waktu yang dibutuhkan untuk sampai ketempat wisata, biaya untuk transportasi dan banyaknya kendaraan ketempat wisata. Fasilitas pendukung tambahan (Ancilliary) adalah fasilitas pendukung yang digunakan oleh wisatawan, seperti bank, telekomunikasi, pos, rumah sakit, dan sebagainya

Keberadaan sumber daya manusia berperan penting dalam pengembangan pariwisata (Kahsay, 2018). Sumber daya manusia merupakan aset organisasi karena memegang peranan penting dalam membentuk dan mencapai tujuan organisasi. Sikula (1976:23) mendefinisikan "administrasi personalia (personnel administration) sebagai penarikan, seleksi, penempatan, indoktrinasi, pelatihan dan pengembangan sumber daya manusia (tenaga kerja) oleh dan di dalam sebuah perusahaaan". Definisi ini memberi penekanan pada fungsi pengadaan karyawan di dalam sebuah organisasi. Mondy dan Noe (2005:43) mendefinisikan "manajemen sumber daya manusia sebagai pendayagunaan sumber daya manusia untuk mencapai tujuan organisasi”.

Menurut Mangkunegara (2013:2), "manajemen sumber daya manusia merupakan suatu perencanaan, pengorganisasian, pengkoordinasian, pelaksanaan, dan pengawasan terhadap pengadaan, pengembangan, pemberian balas jasa, pengintegrasian, dan pemisahan tenaga kerja dalam rangka mencapai tujuan organisasi". Manajemen sumber daya manusia memiliki tujuan seperti: 1) Memberikan pertimbangan manajemen dalam membuat kebijakan sumber daya manusia untuk memastikan bahwa organisasi memiliki pekerja yang bermotivasi dan berkinerja yang tinggi, memiliki pekerja yang selalu siap mengatasi perubahan dan memenuhi kewajiban pekerjaan secara legal. 2) Mengimplementasikan dan menjaga semua kebijakan dan prosedur sumber daya manusia yang memungkinkan organisasi mampu mencapai tujuannya. 3) Membantu mengambangkan arah organisasi dan strategi, khususnya yang berkaitan dengan implikasi sumber daya manusia. 4) Memberi dukungan yang akan membantu manajer lini mencapai tujuannya. 5) Menangani krisis dan situasi sulit dalam hubungan antar pekerja untuk meyakinkan bahwa mereka tidak menghambat organisasi dalam mencapai tujuannya. 6) Menyediakan sarana komunikasi antara pekerja dan manajemen organisasi. 7) Bertindak sebagai pemelihara standar organisasional dan nilai dalam manajemen sumber daya manusia. Dengan semakin berkembangnya industri pariwisata, semakin banyak jenis akomodasi yang disediakan.

Resort merupakan salah akomodasi di industri di pariwisata. Menurut Ali (2013: 9-26) "resort hotel memiliki fasilitas layanan berkualitas, menyenangkan lingkungan fisik, memberikan hiburan yang nyaman, dan memiliki lokasi unik, pemandangan yang indah alami, dan tempattempat rekreasi". Keberadaan sumber daya manusia berperan penting dalam pengembangan pariwisata. Sumber daya manusia akan menciptakan keberhasilan khususnya dalam industri hospitality, sehingga karyawan dalam sebuah perusahaan memiliki peranan yang sangat penting dalam rangka meningkatkan kualitas pelayanan jasa. 
Menurut Febri Ananta (2016: 2) "sumber daya manusia dikatakan produktif, apabila dapat menyelesaikan tugas dan tanggung jawabnya secara tepat waktu". Produktivitas karyawan menjadi suatu kunci yang menentukan keberhasilan suatu perusahaan. Menurut Hasibuan dalam Edyun (2012:156) "produktivitas adalah meningkatnya output (hasil) yang sejalan dengan input (masukan)". Jika produktivitas naik ini hanya dimungkinkan oleh adanya peningkatan efisiensi (waktu,bahan,tenaga) dan sistem kerja, teknik produksi dan adanya peningkatan keterampilan dari tenaga kerjanya.

Menurut Wexley dan Yukl dalam Edyun (2012:157) pengertian produktivitas adalah "produktivitas kerja karyawan dari suatu organisasi memegang peranan yang sangat penting". Maju atau mundurnya organisasi sangat tergantung pada naik turunnya produktivitas kerja karyawan. Karyawan yang melakukan suatu pekerjaan tertentu dapat dipastikan akan memperoleh hasil. Hasil merupakan output dari produksi suatu aktivitas kerja. Produksi merupakan usaha untuk menghasilkan barang atau jasa, dan produktivitas berkaitan erat sebagai cara pencapaian tingkat produksi tersebut.

Menurut Internasional Labour Organisation dalam Solihah (2012:207) adalah "tingkat efisiensi pemanfaatan setiap elemen yang digunakan untuk produksi pada waktu tertentu". Cascio dalam Almigo (2004:48) "performance appraisal atau penilaian kerja yang merupakan suatu penggambaran sistematis tentang individu atau kelompok yang berkaitan dengan kelebihan dan kekurangan dalam suatu pekerjaan sebagai bentuk evaluasi bagi individu yang berkaitan dengan pelaksanaan organisasinya".

Produktivitas adalah kemampuan menghasilkan barang/jasa dari berbagai sumber daya dan kemampuan yang dimiliki oleh setiap pekerja/karyawan. Produktivitas merupakan kemampuan meningkatkan hasil kerja karyawan yang ditinjau dari sumber daya yang dimiliki oleh setiap masing-masing individu. Menurut Jackson dalam Agustin (2014:90) "produktivitas (productivity) diartikan meningkatnya hasil kerja yang dipengaruhi oleh kemampuan para karyawan (input) dan menghasilkan sebuah barang atau jasa (output)". Menurut Manullang, dalam Edyun (2012: 67) ada faktor-faktor yang mempengaruhi produktivitas kerja yakni: 1)Keahlian, merupakan faktor yang harus dimiliki oleh pengawas pelaksana maupun pemimpin. 2) Pengalaman, faktor yang erat hubungannya dengan intelegensi, yaitu kesanggupan karyawan untuk menyelesaikan tugas-tugas dengan hasil yang tidak ditentukan oleh pengalaman tertentu tapi juga harus didukung oleh intelegensi. 3) Umur, karyawan yang sudah berumur lanjut mempunyai tenaga fisik relative terbatas daripada karyawan yang masih muda, untuk itu lebih banyak mengenakan karyawan y ang lebih muda karena fisiknya lebih kuat. 4) Keadaan fisik, erat hubungannya dengan tugas yang dihadapi. Seperti pekerjaan yang membutuhkan tenaga fisik. 5) Pendidikan, memberikan pelatihanyang menunjukan kesanggupan kerja. 6) Bakat dan temperamen, berhubungan dengan sifat-sifat khusus dari kepribadian seseorang yang tidak dipengaruhi oleh alam sekitar.

Menurut Cetin (2016: 70-79) "faktor yang mempengaruhi produktivitas karyawan salah satunya adalah motivasi kerja". Menurut Sulistiyani (2003: 58), "motivasi adalah proses pemberian dorongan kepada anak buah agar anak buah dapat bekerja sejalan dengan batasan yang diberikan guna mencapai tujuan organisasi secara optimal". Menurut Stears dalam Sedarmayanti (2009: 233), "motivasi adalah kekuatan kecenderungan seorang individu melibatkan diri dalam kegiatan yang berarahkan sasaran dalam pekerjaan". Dalam hal ini yang menjadi fokusnya perasaan bersedia/rela bekerja untuk mencapai tujuan pekerjaan.

Menurut Siagian (2009: 102), menyatakan bahwa "motivasi merupakan daya dorong bagi seseorang untuk memberikan kontribusi yang sebesar mungkin demi keberhasilan organisasi mencapai tujuannya". Menurut Samsudin (2010: 281) mengemukakan bahwa "motivasi adalah proses mempengaruhi atau mendorong dari luar terhadap seseorang atau kelompok kerja agar mereka mau melaksanakan sesuatu yang telah ditetapkan”. Liang Gie (2007) dalam Samsudin (2010:282) menyatakan bahwa "motivasi adalah pekerjaan yang dilakukan oleh manajer dalam memberikan inspirasi, semangat dan dorongan kepada orang lain, dalam hal ini karyawannya, untuk mengambil tindakan-tindakan tertentu".

Menurut Hasibuan (2003:125) mengemukakan bahwa "motivasi di dalam suatu organisasi mempunyai maksud dan tujuan yang sangat luas dalam rangka pengembangan organisasi tersebut", antara lain: 1) Meningkatkan semangat kerja pegawai atau karyawan. 2) Meningkatkan kepuasan 
kerja karyawan, 3) Meningkatkan produktifitas karyawan. 4)Meningkatkan loyalitas dan integritas karyawan. 5) Meningkatkan kedisiplinan karyawan. 6)Meningkatkan kehadiran kerja karyawan.

Penelitian ini memilih lokasi di Komaneka Bisma dikarenakan persentase okupansi kamar di Komaneka Bisma pada tahun 2019 mengalami fluktuatif yaitu mengalami peningkatan dan penurunan apabila dilihat dari bulan februari, maret, april dan mei di tahun 2019 dibandingkan dengan tahun 2018.

Tabel 1. Perbandingan Persentase Okupansi Kamar periode Bulan Januari-Bulan Juni 2018 dan 2019 di Komaneka Bisma Ubud

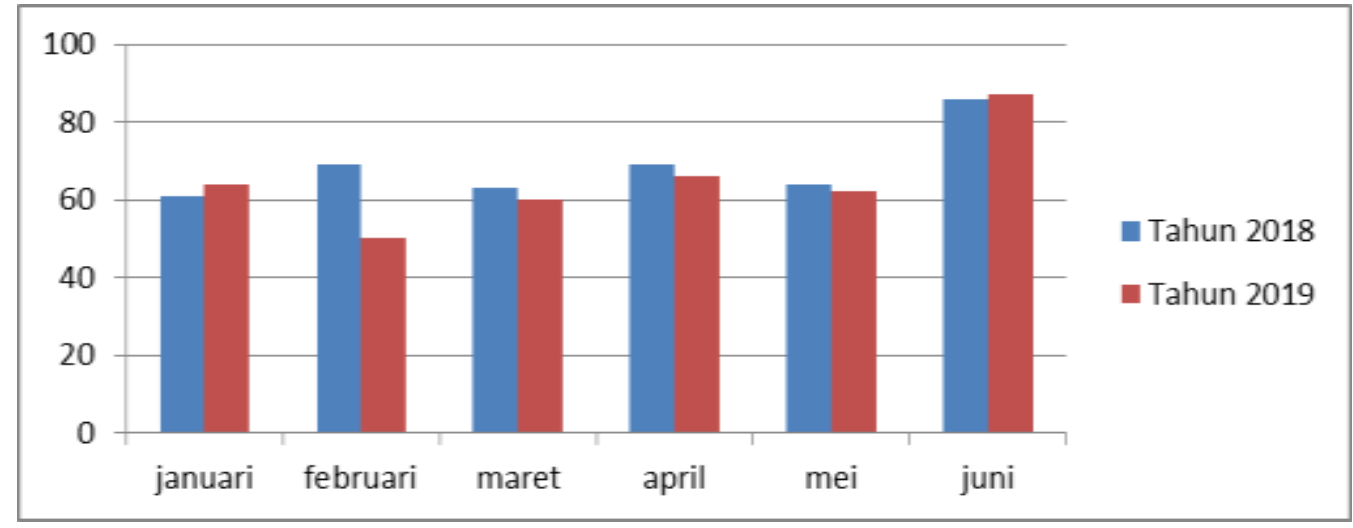

Sumber: Komaneka Bisma Ubud, 2019

Berdasarkan pada Tabel 1 dapat dijelaskan bahwa persentase okupansi kamar di Komaneka Bisma pada tahun 2019 mengalami fluktuatif, adapun pada bulan februari mengalami penurunan yang drastis dikarenakan adanya pada bulan februari merupakan masa kampanye pemilihan presiden dan wakil presiden, sehingga beberapa negara memberikan peringatan kepada warga negaranya untuk datang ke Indonesia.

Selain dilihat dari persentase okupansi kamar, penurunan produktivitas karyawan dapat dilihat melalui penilaian yang diberikan oleh tamu terhadap kualiatas pelayanan yang diberikan selama menginap menjadi salah satu faktor yang mempengaruhi okupansi kamar yang dapat dilihat melalui guest comment yang diberikan.

Tabel2. Guest Comment Bulan Januari-Juni 2019

\begin{tabular}{cccc}
\hline Bulan & Positif & Negatif & Jumlah \\
\hline Januari & 15 & 2 & 17 \\
\hline Februari & 13 & 3 & 16 \\
\hline Maret & 17 & 6 & 23 \\
\hline April & 15 & 4 & 19 \\
\hline Mei & 14 & 3 & 17 \\
\hline Juni & 19 & 1 & 20 \\
\hline Jumlah & 93 & 17 & 112 \\
\hline
\end{tabular}

Sumber: Komaneka Bisma Ubud, 2019

Pada Tabel 2 dapat dilihat bahwa guest comment bulan Januari sampai dengan Juni 2019 adalah 112, yang terdiri dari 93 komentar positif dan sebanyak 17 komentar negatif. Standar dari komentar negatif yang seharusnya diterima setiap bulan adalah minimal satu berdasarkan pada Standar Operasional Prosedur yang dimiliki oleh Komaneka Bisma. Hal ini menunjukkan bahwa terdapat beberapa hal yang kurang memuaskan yang diterima oleh tamu selama menginap di Komaneka Bisma.

Dalam hal ini tidak terlepas dari adanya guest complaint selama menginap di Komaneka Bisma. Guest Complain periode bulan Januari sampai dengan bulan Juni 2019 dengan persentase tertinggi dari tiga keluhan yakni keluhan service (pelayanan) dengan 20,3\%, sedangkan keluhan yang jarang terjadi yaitu keluhan mengenai karyawan yakni sebanyak 17,8\% selama periode bulan 
Januari sampai dengan bulan Juni 2019. Adapun guest complaint periode bulan Januari - bulan Juni 2019 dapat dilihat pada tabel di bawah ini.

Tabel3. Guest Complain Periode Bulan Januari-Juni2019

\begin{tabular}{cccc}
\hline Bulan & Service $(\boldsymbol{\%})$ & Fasilitas $(\%)$ & Karyawan $(\%)$ \\
\hline Januari & 3,7 & 3,3 & 3,0 \\
\hline Februari & 3,7 & 3,2 & 3,9 \\
\hline Maret & 4,2 & 4,5 & 3,1 \\
\hline April & 3,6 & 4,7 & 3,9 \\
\hline Mei & 4,6 & 3,4 & 2,9 \\
\hline Juni & 0,5 & 1,9 & 1,0 \\
\hline Jumlah & 20,3 & 21 & 17,8
\end{tabular}

Sumber: Komaneka Bisma Ubud, 2019

Berdasarkan pada Tabel 3 dapat dilihat bahwa guest complain periode bulan Januari sampai dengan bulan Juni 2019 service (pelayanan) dengan 20,3\%, yang terjadi adalah mengenai estimasi waktu dalam proses check in check out, dalam memberikan pelayanan room service, kebersihan kamar tamu. Adanya guest complain di fasilitas dengan jumlah total yaitu $21 \%$ yang dinilai dari keadaan air conditioner yang tidak berfungsi dengan baik dan shower yang mengeluarkan debit air dalam jumlah kecil. Sedangkan guest complain karyawan dengan total jumlah 17,8\% diniliai dari karamah tamahan dari karyawan yang dirasa kurang oleh tamu.

Berdasarkan fenomena-fenomena di atas yang disertai dengan Komaneka Bisma merupakan salah satu resorts yang menggunakan manajemen lokal di Ubud sehingga selaras dengan tujuan dari penelitian ini yaitu untuk mengetahui pengaruh motivasi kerja terhadap produktivitas karyawan di Komaneka Resorts, Komaneka Bisma Ubud dan untuk mengetahui seberapa besar motivasi kerja memberikan pengaruh terhadap produktivitas karyawan di Komaneka Resorts, Komaneka Bisma Ubud. Sehingga dapat membantu memberikan sumbangsih pemikiran dan menjadi bahan masukan kepada human resources mengenai motivasi kerja terhadap produktivitas karyawan operasional di Komeneka Resorts, Komaneka Bisma Ubud.

\section{METODE PENELITIAN}

Penelitian ini dilakukan di Komaneka Resorts, Komaneka Bisma Ubud. Komaneka Bisma terletak di J1. Bisma, Ubud, Kabupaten Gianyar, Bali. Komaneka Bisma berdiri pada tahun 2008 seluas 5 hektar yang membentang di sepanjang satu sisi ngarai sungai tjampuhan, dengan pemandangan ke hutan hujan tropis.

Komaneka Bisma Ubud terletak di pusat Ubud yang strategis, namun untuk menuju Bandara Internasional I Gusti Ngurah Rai memerlukan waktu tempuh satu jam tiga puluh menit. Adapun beberapa destinasi wisata yang berada di sekitar resort yang berada di ubud yakni Campuhan Ridge Walk, Museum Puri Lukisan, Puri Saren Agung, Sacred Monkey Forest Sanctuary, Agung Rai Museum of Art, dan Neka Museum Art. Sedangkan untuk wisata kuliner terdapat beberapa referensi yakni British Restaurant, Starbucks Monkey Forest, Watercress Cafe Ubud, Bali Pesto Cafe Ubud, Family Restaurant, Nasi Ayam Kedewatan, Bali Buda Café \& Health Food Shops Ubud, Bebek Bengil Ubud, Restoran Bebek Tepi Sawah, Bridges Restaurant, Green Kubu Cafe, Folk Pool \& Gardens, Rondji Restaurant, dan Terracotta Restaurant.

Jenis data yang digunakan adalah data kualitatif yaitu data yang dikumpulkan tidak bernilai numerik, melainkan berupa informasi atau keterangan yang berhubungan dengan permasalahan yang diteliti yaitu dalam bentuk kata, skema dan gambar, dan kuantitatif yaitu data yang berupa angka-angka. Sumber data yang digunakan adalah data primer yaitu informasi yang diperoleh dari lokasi penelitian yang dilakukan melalui pengamatan langsung (observasi), dan wawancara dan data sekunder yaitu informasi yang diperoleh dari lokasi penelitian yang dilakukan melalui pengamatan langsung (observasi) serta wawancara.

Dengan teknik pengumpulan data yang digunakan adalah : 1) observasi yaitu kegiatan pemuatan penelitian terhadap suatu objek, 2) wawancara yakni dilakukan dengan cara mengajukan 
beberapa pertanyaan kepada narasumber untuk mendapat jawaban langsung, 3) studi kepustakaan berkaitan dengan kajian teoritis dan referensi lain yang berkaitan dengan nilai, budaya dan norma yang berkembang pada situasi sosial yang diteliti, serta berkaitan dengan literatur-literatur Ilmiah, 4) kuesioner yakni teknik pengumpulan data yang dilakukan dengan cara memberikan seperangkat pertanyaan atau pernyataan tertulis kepada responden untuk dijawab dan 5) dokumentasi yaitu mencari dan mengumpulkan data, mengenai hal-hal yang berupa catatan,transkrip, agenda, dan sebagainya. Adapun teknik penentuan responden menggunakan sampling jenuh yaitu teknik penentuan sampel menggunakan semua anggota populasi digunakan sebagai sampel. Penelitian ini menggunakan sampel jenuh seluruh karyawan operasional di Komaneka Bisma dengan total karyawan 112 orang.

Penelitian ini menggunakan teknik analisis data kuantitatif yaitu mengolah data dengan mentabulasi, menghitung dan menguji dengan menggunakan bantuan bantuan software. Teknik analisis data kuantitaif dibagi menjadi dua yaitu statitistik deskriptif dan statistik inferensial. Statistik deskriptif adalah statistik yang digunakan untuk menganalisis data dengan cara mendeskripsikan atau menggambarkan data yang telah terkumpul sebagaimana adaya tanpa bermaksud membuat kesimpulan yang berlaku untuk umum atau generalisasi. Sedangkan statistik inferensial adalah teknik statistik yang digunkaan untuk menganalisis data sampel dan hasilnya diberlakukan untuk populasi.

Analisis statistik deskriptif digunakan untuk menghitung dan menganalisa kuesioner karyawan dengan menggunakan skala likert. Statistik inferensial atau probabilitas adalah teknik statistik yang digunakan untuk menganalisis data sampel dan hasilnya diberlakukan populasi. Analisis statistik deskriptif digunakan untuk menghitung dan menganalisa kuesioner karyawan dengan menggunakan skala likert. Skala likert dibagi sebagai berikut : skor 1 (Sangat Tidak Setuju), Skor 2 (Tidak Setuju), Skor 3 (Setuju) dan Skor 4 (Sangat Setuju). Pemilihan 4 rent ang skor ini didasari pada asumsi agar responden tidak menjawab ragu-ragu/netral pada skala berjumlah 5. Untuk mengetahui intensitas karyawan, dibuat kategori sikap dengan mencari terlebih dahulu rentang nilainya dengan rumus dibawah ini

$$
\begin{gathered}
\frac{\text { Skor tertinggi-gkor terendah }}{\text { Jumlah kelas }}=\text { Rentang/interval } \\
\frac{4-1}{5}=0,6
\end{gathered}
$$

1) $1,00-1,60:$ Termasuk kategori sangat tidak setuju

2) $1,61-2,21:$ Termasuk kategori tidak setuju

3) $2,22-2,82$ : Termasuk kategori setuju

4) $2,83-3,43$ : Termasuk kategori sangat setuju

Untuk mengetahui dengan jelas pengaruh motivasi kerja terhadap produktivitas karyawan, dapat dilihat pada tabel di bawah ini

Tabel4. Skala Likert

\begin{tabular}{|c|l|c|c|}
\hline No. & \multicolumn{1}{|c|}{ Kategori } & Skor & Rentang nilai (interval) \\
\hline 1 & Sangat Tidak Setuju & 1 & $1,00-1,60$ \\
\hline 2 & Tidak Setuju & 2 & $1,61-2,21$ \\
\hline 3 & Setuju & 3 & $2,22-2,82$ \\
\hline 4 & Sangat Setuju & 2 & $2,83-3,43$ \\
\hline
\end{tabular}

Sumber :Modifikasi Skala Likert Utama, 2016

Sedangkan teknik analisis data kualitatif adalah mengumpulkan data hasil wawancara dan observasi parisipatoris serta menguraikannya dalam bentuk narasi. Pada penelitian ini menggunakan teknik analisis data kuantitatif statistik deskriptif dan statistik inferensial.

Adapun uji instrument yang digunakan yakni: 1) uji validitas yakni validitas menentukan alat ukur tersebut dapat digunakan untuk mengukur apa yang seharusnya diukur, 2) uji reliabilitas 
yaitu uji reliabilitas atau keandalan intsrumen menentukan sejauh mana suatu pengkuran dapat memberikan hasil yang konsisten bila dilakukan pengukuran kembali dengan gejala yang sama, 3) uji normalitas digunakan untuk menguji model regresi, variabel terikat, variabel bebas atau keduanya memiliki distribusi normal atau tidak, 4) analisis regresi linear sederhana digunakan untuk melakukan prediksi seberapa besar nilai variabel dependent jika nilai independent dirubah, 5) uji $t_{\text {test }}$ untuk menguji apakah masing-masing variabel independen berpengaruh pada variabel dependen, dan 6) koefisien determinasi digunakan untuk mengetahui seberapa besar persentase dari pengaruh variabel independe terhadap variabel dependen.

\section{HASIL DAN PEMBAHASAN}

\subsection{Hasil}

Motivasi kerja dan produktivitas karyawan di Komaneka Bisma Ubud dilakukan dengan menggunakan Skala Likert. penilaian ini bertujuan untuk mengetahui tanggapan umum responden terhadap variabel penelitian yang dinyatakan dalam skala likert. Penilaian responden akan diklasifikasikan ke dalam 4 skala, mulai dari yang terendah dengan nilai 1, hingga yang tertinggi dengan nilai 4.

Pada pengukuran menggunakan skala likert ini terdapat variabel dependent yakni motivasi kerja dan variabel independent yakni produktivitas yang masing variabel memiliki indikator. Motivasi kerja adalah dorongan atau perangsang yang membuat seseorang melakukan pekerjaan yang diinginkannya dengan rela tanpa merasa terpaksa sehingga pekerjaan yang dilakukan dapat berjalan dengan baik atau menghasilkan sesuatu yang memuaskan.

3.1.1 Karakteristik Responden

Tabel5. Karakteristik Responden Berdasarkan Umur

\begin{tabular}{ccc}
\hline Rentang Usia & Jumlah Responden & Persentase (\%) \\
\hline $20-25$ & 35 & 31,25 \\
\hline $26-30$ & 26 & 23,21 \\
\hline $31-35$ & 32 & 27,67 \\
\hline $36-40$ & 14 & 12,05 \\
\hline $41-45$ & 5 & 5,82 \\
\hline Jumlah & $\mathbf{1 1 2}$ & $\mathbf{1 0 0}$ \\
\hline
\end{tabular}

Sumber: Hasil Penelitian, 2019

Tabel 5 dapat dilihat bahwa jumlah reponden terbanyak yaitu rentang umur 20-25 tahun yang berjumlah 35 orang dengan persentase $31,25 \%$. Sedangkan jumlah responden terendah berumur 41-45 tahun paling sedikit yaitu berjumlah 5 orang dengan persentase $5,82 \%$. Hal tersebut menunjukan bahwa mayoritas karyawan yang bekerja di Komaneka Bisma berusia muda.

Tabel6. Karakteristik Responden Berdasarkan Jenis Kelamin

Jenis Kelamin

Jumlah Responden

Persentase (\%)

\begin{tabular}{ccc}
\hline Laki-Laki & 63 & 56,25 \\
\hline Perempuan & 49 & 43,75 \\
\hline Jumlah & $\mathbf{1 1 2}$ & $\mathbf{1 0 0}$ \\
\hline
\end{tabular}

Sumber: Hasil Penelitian, 2019

Tabel 6 dapat dilihat bahwa responden dengan jenis kelamin laki-laki jumlahnya lebih banyak dibandingkan responden dengan jenis kelamin perempuan, yaitu dengan jumlah 63 orang atau 56,25\% dari jumlah responden. Adapun responden dengan jenis kelamin perempuan berjumlah 49 orang dengan persentasi $43,75 \%$ dari jumlah keseluruhan responden. 
Tabel 7.Karakteristik Responden Berdasarkan Departemen

\begin{tabular}{ccc}
\hline Departemen & Jumlah Responden & Persentase (\%) \\
\hline Front Office & 15 & 13,39 \\
\hline FBP & 15 & 13,39 \\
\hline FBS & 19 & 16,96 \\
\hline Engineering & 7 & 6,25 \\
\hline Housekeeping & 39 & 34,82 \\
\hline Spa & 8 & 7,14 \\
\hline Security & 9 & 8,05 \\
\hline Jumlah & $\mathbf{1 1 2}$ & $\mathbf{1 0 0}$
\end{tabular}

Sumber: Hasil Penelitian, 2019

Tabel 7 dapat dilihat bahwa responden yang yang paling banyak adalah departemen housekeeping yakni sebanyak 39 orang, hal ini dikarenakan keluarga besar Komaneka memberikan pelayanan dengan make up room ketika tamu sedang tidak berada di kamar sehingga memberikan kejutan kepada tamu dengan tampilan kamar yang bersih dan rapi setelah ditinggal pergi.

Kemudian tim food and beverage service yang memberikan responden berjumlah 19 orang karyawan, dari department front office dan food and beverage product berjumlah 15 orang karyawan, security berjumlah 9 orang karyawan, spa sebanyak 8 orang karyawan, dan engineering berjumlah 7 orang karyawan.

Tabel 8. Karakteristik Responden Berdasarkan Pendidikan

\begin{tabular}{cccc}
\hline No & Tingkat Pendidikan & Jumlah & Persentase (\%) \\
\hline 1 & SMP & 3 & 2,68 \\
\hline 2 & SMK & 56 & 50 \\
\hline 3 & Diploma I & 14 & 12,5 \\
\hline 4 & Diploma II & 22 & 19,64 \\
\hline 5 & Diploma III & 3 & 2,68 \\
\hline 6 & S1 & 14 & 12,5 \\
\hline & Jumlah & $\mathbf{1 1 2}$ & $\mathbf{1 0 0}$
\end{tabular}

Sumber: Hasil Penelitian, 2019

Tabel 8 dapat dilihat bahwa responden yang berpendidikan pada sekolah menengah pertama (SMP) sebanyak 3 orang atau $2.68 \%$, untuk responden yang berpendidikan pada sekolah menengah kejuruan (SMK) sebanyak 56 orang atau 50\%. Responden yang berpendidikan Diploma I sebanyak 14 orang atau $12.5 \%$, responden yang berpendidikan Diploma II sebanyak 22 orang atau $19.64 \%$, dan responden yang berpendidikan S1 sebanyak 14 orang atau $12.5 \%$. berdasarkan pada jumlah responden yang mengisi kuesioner jumlah pendidikan yang paling banyak adalah responden yang menyelesaikan pendidikannya di sekolah menengah kejuruan (SMK).

\subsubsection{Hasil Penilaian Responden}

Tabel 9. Ha sil Penilaian Responden terhadap Motivasi Kerja

\begin{tabular}{|c|c|c|c|c|c|c|c|c|c|}
\hline \multirow{3}{*}{ No } & \multirow{3}{*}{$\begin{array}{l}\text { Indikator } \\
\text { Variabel }\end{array}$} & \multicolumn{4}{|c|}{ Skor Frekuensi Pernyataan } & \multirow{3}{*}{$\begin{array}{l}\text { Total } \\
\text { Skor }\end{array}$} & \multirow{3}{*}{$\begin{array}{c}\text { Jumlah } \\
\text { Responden }\end{array}$} & \multirow{3}{*}{$\begin{array}{l}\text { Rata- } \\
\text { Rata } \\
\text { Skor }\end{array}$} & \multirow{3}{*}{ Ket } \\
\hline & & SS & $\mathbf{S}$ & TS & STS & & & & \\
\hline & & 4 & 3 & 2 & 1 & & & & \\
\hline 1 & $\begin{array}{l}\text { Anda } \\
\text { termotivasi } \\
\text { untuk } \\
\text { mendapatkan } \\
\text { promosijabatan }\end{array}$ & 11 & 62 & 31 & 8 & 300 & 112 & 2,68 & Setuju \\
\hline
\end{tabular}




\begin{tabular}{|c|c|c|c|c|c|c|c|c|c|}
\hline & $\begin{array}{l}\text { karena tanggung } \\
\text { jawab yang } \\
\text { lebih besar }\end{array}$ & & & & & & & & \\
\hline 2 & $\begin{array}{l}\text { Anda } \\
\text { termotivasi } \\
\text { untuk } \\
\text { mendapatkan } \\
\text { promosi jabatan } \\
\text { karena adanya } \\
\text { tambahan } \\
\text { pembayaran } \\
\text { upah }\end{array}$ & 16 & 58 & 35 & 3 & 311 & 112 & 2,78 & Setuju \\
\hline 3 & $\begin{array}{l}\text { Anda } \\
\text { termotivasi } \\
\text { untuk } \\
\text { meningkatkan } \\
\text { presta si kerja } \\
\text { untuk } \\
\text { pengembangan } \\
\text { karier }\end{array}$ & 25 & 41 & 40 & 6 & 309 & 112 & 2,76 & Setuju \\
\hline 4 & $\begin{array}{l}\text { Anda } \\
\text { termotivasi } \\
\text { dengan jenis } \\
\text { pekerjaan Anda } \\
\text { saat ini }\end{array}$ & 14 & 48 & 46 & 4 & 296 & 112 & 2,64 & Setuju \\
\hline 5 & $\begin{array}{l}\text { Anda } \\
\text { termotivasi } \\
\text { dengan } \\
\text { pekerjaan } \\
\text { karena } \\
\text { mendapatkan } \\
\text { penghargaan } \\
\end{array}$ & 8 & 58 & 36 & 10 & 288 & 112 & 2,57 & Setuju \\
\hline 6 & $\begin{array}{l}\text { Anda } \\
\text { termotivasi } \\
\text { karena diberikan } \\
\text { tanggungjawab } \\
\text { meneyelesaikan } \\
\text { pekerjaan }\end{array}$ & 12 & 54 & 44 & 2 & 300 & 112 & 2,68 & Setuju \\
\hline 7 & $\begin{array}{l}\text { Anda } \\
\text { termotivasi } \\
\text { karena } \\
\text { kemampuan dan } \\
\text { keahlian Anda } \\
\text { menda patkan } \\
\text { penga kuan dari } \\
\text { pihak } \\
\text { manajemen } \\
\end{array}$ & 9 & 56 & 43 & 4 & 294 & 112 & 2,63 & Setuju \\
\hline 8 & $\begin{array}{l}\text { Anda } \\
\text { termotivasi } \\
\text { karena } \\
\text { keberhasilan } \\
\text { menyelesaikan } \\
\text { pekerjaan } \\
\text { memberikan } \\
\text { rasa bangga } \\
\end{array}$ & 13 & 53 & 45 & 1 & 302 & 112 & 2,69 & Setuju \\
\hline & Total & 108 & 430 & 320 & 38 & & & 21,43 & Setuju \\
\hline
\end{tabular}




\begin{tabular}{|c|c|c|c|c|l|l|l|}
\hline Rata-rata & 13,5 & 53,7 & 40 & 4,7 & 2,68 & \\
\hline
\end{tabular}

Sumber : Hasil Penelitian, 2019

Berdasarkan Tabel 9 dapat dilihat karyawan di Komaneka Bisma termotivasi dengan pekerjaan yang sedang dikerjakan. Hasil tabulasi karyawan secara menyeluruh mendapatkan skor 2,68 yang berada pada kriteria setuju. Adapun setiap indikator berada pada kriteria setuju. Skor tertinggi berada pada indikator "Anda termotivasi untuk mendapatkan promosi jabatan karena adanya tambahan pembayaran upah" $(2,78)$, sehingga dengan adanya tambahan upah yang diberikan akan meningkatkan motivasi kerja karyawan di Komaneka Bisma Ubud. Skor terendah berada pada indikator penghargaan, namun indikator tersebut masih berada pada penilaian setuju 2,57 (Interval 2,22-2,82).

Tabel 10. Hasil Penilaian Responden terhadap Produktivitas

\begin{tabular}{|c|c|c|c|c|c|c|c|c|c|}
\hline \multirow{3}{*}{ No } & \multirow{3}{*}{$\begin{array}{l}\text { Indikator } \\
\text { Variabel }\end{array}$} & \multicolumn{4}{|c|}{$\begin{array}{c}\text { Skor Frekuensi } \\
\text { Pernyataan }\end{array}$} & \multirow{3}{*}{$\begin{array}{l}\text { Total } \\
\text { Skor }\end{array}$} & \multirow{3}{*}{$\begin{array}{c}\text { Jumlah } \\
\text { Responden }\end{array}$} & \multirow{3}{*}{$\begin{array}{l}\text { Rata- } \\
\text { Rata } \\
\text { Skor }\end{array}$} & \multirow{3}{*}{ Ket } \\
\hline & & SS & $\mathbf{S}$ & TS & STS & & & & \\
\hline & & 4 & 3 & 2 & 1 & & & & \\
\hline 1 & $\begin{array}{l}\text { Anda mampu } \\
\text { menyelesaika } \\
\mathrm{n} \mathrm{banyak} \\
\text { pekerjaan } \\
\text { dalam satu } \\
\text { waktu (shift) }\end{array}$ & 15 & 71 & 26 & 0 & 325 & 112 & 2,90 & $\begin{array}{l}\text { Sangat } \\
\text { Setuju }\end{array}$ \\
\hline 2 & $\begin{array}{l}\text { Anda dapat } \\
\text { menyelesaika } \\
\mathrm{n} \text { pekerjaan } \\
\text { sesuaidengan } \\
\text { yang } \\
\text { ditargetkan } \\
\text { manajemen }\end{array}$ & 26 & 67 & 19 & 0 & 343 & 112 & 3,06 & $\begin{array}{l}\text { Sangat } \\
\text { Setuju }\end{array}$ \\
\hline 3 & $\begin{array}{l}\text { Anda mampu } \\
\text { menyelesaika } \\
\mathrm{n} \text { pekerjaan } \\
\text { sesuaidengan } \\
\text { standar } \\
\text { perusahaan }\end{array}$ & 13 & 76 & 23 & 0 & 326 & 112 & 2,91 & $\begin{array}{l}\text { Sangat } \\
\text { Setuju }\end{array}$ \\
\hline 4 & $\begin{array}{l}\text { Anda mampu } \\
\text { menyelesaika } \\
\mathrm{n} \text { pekerjaan } \\
\text { secara teknis } \\
\text { dan } \\
\text { menunjukkan } \\
\text { hasil kerja } \\
\text { kepada pihak } \\
\text { manajemen }\end{array}$ & 8 & 85 & 19 & 0 & 325 & 112 & 2,90 & $\begin{array}{l}\text { Sangat } \\
\text { Setuju }\end{array}$ \\
\hline 5 & $\begin{array}{l}\text { Anda mampu } \\
\text { memaksimalk } \\
\text { an waktu yang } \\
\text { tersedia untuk } \\
\text { aktivitas la in }\end{array}$ & 12 & 74 & 26 & 0 & 322 & 112 & 2,88 & $\begin{array}{l}\text { Sangat } \\
\text { Setuju }\end{array}$ \\
\hline 6 & $\begin{array}{l}\text { Anda mampu } \\
\text { menyelesaika } \\
\mathrm{n} \text { pekerjaan } \\
\text { tepatwaktu }\end{array}$ & 19 & 77 & 16 & 0 & 339 & 112 & 3,03 & $\begin{array}{l}\text { Sangat } \\
\text { Setuju }\end{array}$ \\
\hline
\end{tabular}




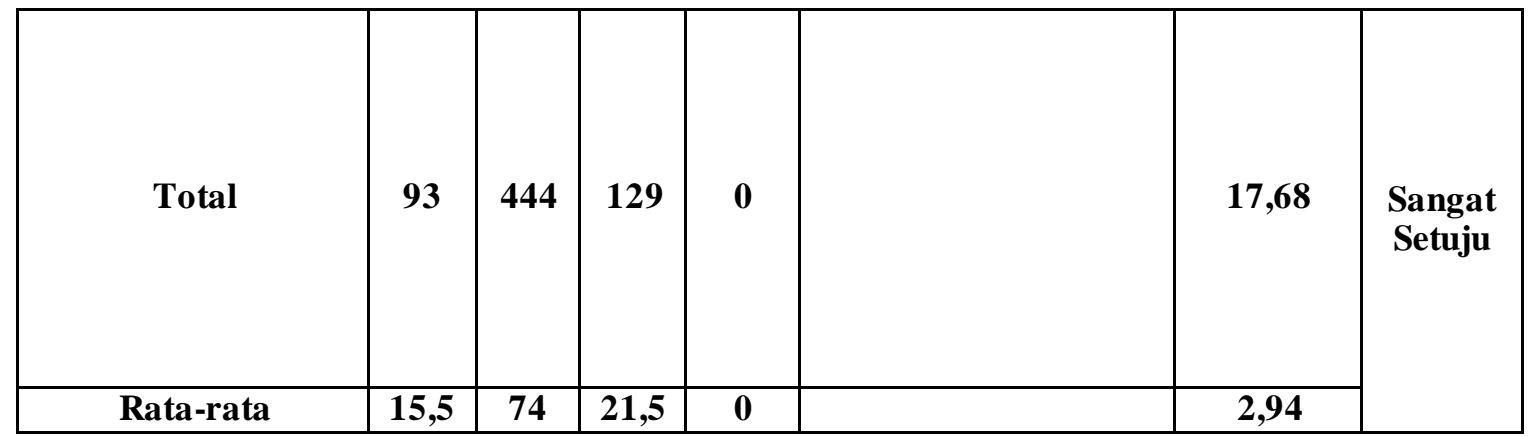

Sumber : Hasil Penelitian, 2019

Berdasarkan Tabel 10 dapat dilihat bahwa karyawan di Komaneka Bisma Ubud menyatakan telah menunjukan produktivitas yang baik. Rata-rata persepsi karyawan pada produktivitas berada pada kriteria sangat setuju dengan skor 2,94 . Skor tertinggi diraih $(3,06)$. Skor terendah rata-rata 2,88 dengan penilaian sangat setuju (interval 2,83-3,43).

Tabel11. Rekapitulasi Responden Motivasi Kerja danProduktivitas

\begin{tabular}{|c|c|c|c|c|c|c|c|c|c|}
\hline \multirow{3}{*}{$\begin{array}{l}\mathbf{N} \\
\mathbf{0}\end{array}$} & \multirow{3}{*}{$\begin{array}{l}\text { Indikator } \\
\text { Variabel }\end{array}$} & \multicolumn{4}{|c|}{ Skor Frekuensi Pernyataan } & \multirow{3}{*}{$\begin{array}{l}\text { Total } \\
\text { Skor }\end{array}$} & \multirow{3}{*}{$\begin{array}{c}\text { Jumlah } \\
\text { Responde } \\
\text { n }\end{array}$} & \multirow{3}{*}{$\begin{array}{l}\text { Rata- } \\
\text { Rata } \\
\text { Skor }\end{array}$} & \multirow{3}{*}{ Ket } \\
\hline & & SS & $\mathbf{S}$ & TS & STS & & & & \\
\hline & & 4 & 3 & 2 & 1 & & & & \\
\hline 1 & $\begin{array}{l}\text { Anda termotivasi } \\
\text { untuk } \\
\text { mendapatkan } \\
\text { promosi jabatan } \\
\text { karena tanggung } \\
\text { jawabyanglebih } \\
\text { besar }\end{array}$ & 11 & 62 & 31 & 8 & 300 & 112 & 2,68 & Setuju \\
\hline & & & & & & & & & \\
\hline 2 & $\begin{array}{l}\text { Anda termotivasi } \\
\text { untuk } \\
\text { mendapatkan } \\
\text { promosi jabatan } \\
\text { karena adanya } \\
\text { tambahan } \\
\text { pembayaran upah }\end{array}$ & 16 & 58 & 35 & 3 & 311 & 112 & 2,78 & Setuju \\
\hline 3 & $\begin{array}{l}\text { Anda termotivasi } \\
\text { untuk } \\
\text { meningkatkan } \\
\text { presta si kerja } \\
\text { untuk } \\
\text { pengembangan } \\
\text { karier }\end{array}$ & 25 & 41 & 40 & 6 & 309 & 112 & 2,76 & Setuju \\
\hline 4 & $\begin{array}{l}\text { Anda termotivasi } \\
\text { dengan jenis } \\
\text { pekerjaan Anda } \\
\text { saatini }\end{array}$ & 14 & 48 & 46 & 4 & 296 & 112 & 2,64 & Setuju \\
\hline 5 & $\begin{array}{l}\text { Anda termotivasi } \\
\text { dengan pekerjaan } \\
\text { karena } \\
\text { mendapatkan } \\
\text { penghargaan }\end{array}$ & 8 & 58 & 36 & 10 & 288 & 112 & 2,57 & Setuju \\
\hline 6 & $\begin{array}{l}\text { Anda termotivasi } \\
\text { karena diberikan } \\
\text { tanggung jawab } \\
\text { meneyelesaikan } \\
\text { pekerjaan }\end{array}$ & 12 & 54 & 44 & 2 & 300 & 112 & 2,68 & Setuju \\
\hline
\end{tabular}




\begin{tabular}{|c|c|c|c|c|c|c|c|c|c|}
\hline 7 & $\begin{array}{l}\text { Anda termotivasi } \\
\text { karena } \\
\text { kemampuan dan } \\
\text { keahlian Anda } \\
\text { mendapatkan } \\
\text { pengakuan dari } \\
\text { pihak manajemen }\end{array}$ & 9 & 56 & 43 & 4 & 294 & 112 & 2,63 & Setuju \\
\hline 8 & $\begin{array}{l}\text { Anda termotivasi } \\
\text { karena } \\
\text { keberhasilan } \\
\text { menyelesaikan } \\
\text { pekerjaan } \\
\text { memberikan rasa } \\
\text { bangga }\end{array}$ & 13 & 53 & 45 & 1 & 302 & 112 & 2,69 & Setuju \\
\hline 9 & $\begin{array}{l}\text { Anda mampu } \\
\text { menyelesaikan } \\
\text { banyak pekerjaan } \\
\text { dalam satu waktu } \\
(\text { shift })\end{array}$ & 15 & 71 & 26 & 0 & 325 & 112 & 2,90 & $\begin{array}{l}\text { Sangat } \\
\text { Setuju }\end{array}$ \\
\hline 10 & $\begin{array}{l}\text { Anda dapat } \\
\text { menyelesaikan } \\
\text { pekerjaan sesuai } \\
\text { dengan yang } \\
\text { ditargetkan } \\
\text { manajemen }\end{array}$ & 26 & 67 & 19 & 0 & 343 & 112 & 3,06 & $\begin{array}{l}\text { Sangat } \\
\text { Setuju }\end{array}$ \\
\hline 11 & $\begin{array}{l}\text { Anda mampu } \\
\text { menyelesaikan } \\
\text { pekerjaan sesuai } \\
\text { dengan standar } \\
\text { perusahaan }\end{array}$ & 13 & 76 & 23 & 0 & 326 & 112 & 2,91 & $\begin{array}{l}\text { Sangat } \\
\text { Setuju }\end{array}$ \\
\hline 12 & $\begin{array}{l}\text { Anda mampu } \\
\text { menyelesaikan } \\
\text { pekerjaan secara } \\
\text { teknis dan } \\
\text { menunjukkan } \\
\text { hasilkerja kepada } \\
\text { pihak manajemen }\end{array}$ & 8 & 85 & 19 & 0 & 325 & 112 & 2,90 & $\begin{array}{l}\text { Sangat } \\
\text { Setuju }\end{array}$ \\
\hline 13 & $\begin{array}{l}\text { Anda mampu } \\
\text { memaksimalkan } \\
\text { waktu yang } \\
\text { tersedia untuk } \\
\text { aktivitas lain }\end{array}$ & 12 & 74 & 26 & 0 & 322 & 112 & 2,88 & $\begin{array}{l}\text { Sangat } \\
\text { Setuju }\end{array}$ \\
\hline 14 & $\begin{array}{l}\text { Anda mampu } \\
\text { menyelesaikan } \\
\text { pekerjaan tepat } \\
\text { waktu }\end{array}$ & 19 & 77 & 16 & 0 & 339 & 112 & 3,03 & $\begin{array}{l}\text { Sangat } \\
\text { Setuju }\end{array}$ \\
\hline & Total & 201 & 880 & 449 & 38 & & & 39.11 & Setuju \\
\hline & Rata-Rata & 14.36 & 62.85 & 32.07 & 2.71 & & & 2.79 & \\
\hline
\end{tabular}

Sumber: Hasil Penelitian, 2019 
Berdasarkan pada Tabel 11 dapat dilihat bahwa pada indikator motivasi kerja yang mendapatkan skor tertinggi adalah promosi jabatan dengan skor 2,79 dengan keterangan setuju. Dilanjutkan dengan indikator pengembangan karir dengan skor 2,76 dengan kategori setuju. Kemudian terdapat indikator pekerjaan memberikan rasa bangga dengan jumlah skor 2,69 dengan keterangan 2,69. Selanjutnya terdapat indikator promosi jabatan dengan tanggung jawab yang lebih besar dengan jumlah skor 2,68 dan indikator tanggung jawab menyelesaikan pekerjaan dengan jumlah skor 2,68 dengan keterangan setuju. Kemudian terdapat indikator pengakuan dengan jumlah skor 2,63 dengan keterangan setuju. Dan indikator penghargaan dengan jumlah skor 2,57 dengan keterangan setuju.

Sedangkan pada produktivitas yang mendapatkan skor tertinggi adalah indikator dapat menyelesaikan pekerjaan sesuai target manajemen dengan jumlah skor 3,06 dengan keterangan sangat setuju. Selanjutnya terdapat indikator menyelesaikan pekerjaan dengan tepat waktu dengan jumlah skor 3,03 dengan keterangan sangat setuju. Kemudian terdapat indikator menyelesaikan pekerjaan sesuai dengan standar perusahaan dengan jumlah skor 2,91 dengan keterangan sangat setuju. Dilanjutkan dengan indikator menyelesaikan banyak pekerjaan dalam satu waktu dengan jumlah skor 2,90 dan indikator menyelesaikan pekerjaan secara teknis dan menunjukkan hasil kerja dengan jumlah skor 2,90 dengan keterangan sangat setuju. Dan indikator yang mendapatkan skor terendah adalah mampu memaksimalkan waktu yang tersedia untuk aktivitas lain dengan jumlah skor 2,88 dengan keterangan sangat setuju.

\subsection{Hasil Uji Instrumen}

Uji instrument penelitian ini dilakukan dengan uji validitas, uji reliabilitas, uji normalitas, koefisien deterinasi, uji hipotesis (Uji t-test). Instrumen yang diuji adalah kuesioner yang berisi 14 pernyataan. Sebuah instrumen dianggap memiliki validitas yang tinggi jika instrumen tersebut benar-benar dapat dijadikan alat untuk mengukur sesuatu secara tepat. Selanjutnya uji reliabilitas untuk mengetahui instrument reliabel bila mampu mengukur sesuatu dengan hasil yang konsisten.

Uji normalitas digunakan untuk menguji apakah dalam model regresi, variabel terikat, variabel bebas atau keduanya memiliki distribusi normal atau tidak. Model regresi yang baik adalah yang memiliki distribusi data normal atau yang mendekati normal. Koefisien determinasi digunakan untuk mengetahui seberapa besar persentase dari pengaruh variabel independen terhadap variabel dependen yaitu pengaruh motivasi kerja terhadap produktivitas. Sedangkan uji hipotesis (uji $t_{\text {-test}}$ ) dilakukan secara parsial terhadap parameter dilakukan dengan menggunakan uji $t_{\text {test }}$. Pengujian ini dilakukan untuk mengetahui signifikansi perbedaan 2 buah mean yang berasal dari 2 buah distribusi atau menguji secara parsial masing-masing setiap variabel dengan membandingkan nilai t-hitung dengan t-tabel

\subsubsection{Uji Validitas}

Sugiyono (2017:203) "validitas menentukan alat ukur tersebut dapat digunakan untuk mengukur apa yang seharusnya diukur". Uji validitas dapat dilakukan terhadap data yang didapat melalui kuesioner. Uji validitas dilakukan untuk menguji hasil kuesioner agar dapat dikatakan valid. Indikator yang diukur yakni indicator motivasi kerja $\left(\mathrm{X}_{1}\right)$ dan produktivitas $(\mathrm{Y})$. pada penelitian ini menggunakan 14 pernyataan yang disebar menggunakan kuesioner, dengan menggunakan rumus Bivariatte Pearson (Product Moment Pearson) yang diolah menggunakan bantuan program SPSS for Windows versi 23.0. Penelitian ini menggunakan tingkat signifikansi sebesar $5 \%$ atau 0.05 . Item pada kuesioner dinyatakan valid apabila nilai $r$-hitung yang dimiliki tiap indikator lebih besar daripada $\mathrm{r}$-tabel $(\mathrm{r}$-hitung $>\mathrm{r}$-tabel $)$. Uji validitas dilakukan pada semua responden yaitu 112 Penelitian ini menggunakan tingkat signifikansi sebesar 5\% atau 0.05. Item pada kuesioner dinyatakan valid apabila nilai $r$-hitung yang dimiliki tiap indikator lebih besar daripada $\mathrm{r}$-tabel $(\mathrm{r}$-hitung $>\mathrm{r}$-tabel). Hasil uji validitas dapat dilihat berdasarkan tabel 12 berikut. Tabel 12. Hasil Uji Validitas

\begin{tabular}{cccccc}
\hline Variabel & & Item & $\mathrm{r}_{\text {hitung }}$ & $\mathrm{r}_{\text {tabel }}$ & Keterangan \\
\hline Motivasi Kerja & $(\mathrm{X} 1)$ & X.1.1 & 0.827 & 0,195 & Valid \\
& & X.1.2 & 0.805 & 0,195 & Valid
\end{tabular}




\begin{tabular}{|c|c|c|c|c|c|}
\hline \multirow{12}{*}{ Produktivitas } & \multirow{12}{*}{$(\mathrm{Y})$} & X.1.3 & 0.861 & 0,195 & Valid \\
\hline & & X.1.4 & 0.856 & 0,195 & Valid \\
\hline & & X.1.5 & 0.865 & 0,195 & Valid \\
\hline & & X.1.6 & 0.834 & 0,195 & Valid \\
\hline & & X.1.7 & 0.804 & 0,195 & Valid \\
\hline & & X.1.8 & 0.813 & 0,195 & Valid \\
\hline & & Y.1.1 & 0.719 & 0,195 & Valid \\
\hline & & Y.1.2 & 0.795 & 0,195 & Valid \\
\hline & & Y.1.3 & 0.75 & 0,195 & Valid \\
\hline & & Y.1.4 & 0.704 & 0,195 & Valid \\
\hline & & Y.1.5 & 0.804 & 0,195 & Valid \\
\hline & & Y.1.6 & 0.753 & 0,195 & Valid \\
\hline
\end{tabular}

Sumber : Hasil output SPSS (23.0), 2019

Berdasarkan pada Tabel 12 dapat dilihat bahwa r-hitung indikator yang diuji dalam penelitian ini keseluruhan menghasilkan nilai positif dan lebih besar dari nilai $\mathrm{r}_{\text {-tabel. }}$. Sehingga dapat disimpulkan bahwa item-item pernyataan indikator dalam kuesioner ini dinyatakan valid.

\subsubsection{Uji Reliabilitas}

Sugiyono (2017:209) "uji reliabilitas atau keandalan intsrumen menentukan sejauh mana suatu pengkuran dapat memberikan hasil yang konsisten bila dilakukan pengukuran kembali dengan gejala yang sama". Rumus mengenai uji reliabilitas menggunakan rumus Cronbach Alpha $>0.60$ yang diolah menggunakan bantuan program SPSS (Statistic Package of Social Science) for Windows 23.0. Uji reliabilitas adalah pengujian yang mengukur tingkat konsisten atau kestabilan data kuesioner. Suatu kuesioner dikatakan reliabel atau handal jika jawaban seseorang terhadap pernyataan konsisten dari waktu ke waktu. Reliabilitas diukur dengan uji statistik cronbach's alpha $(\alpha)$. Suatu variabel dikatakan reliabel jika memberikan nilai cronbach' alpha $>0,60$. Adapun hasil uji reliabilitas dapat dilihat pada tabel berikut.

Tabel 13. Hasil Uji Reliabilitas

\begin{tabular}{clcc}
\hline No & Variabel & Cronbach's Alpha & Hasil \\
\hline 1 & Motivasi Kerja (X1) & 0,936 & Reliabel \\
2 & Produktivitas (Y) & 0,848 & Reliabel \\
\hline
\end{tabular}

Sumber : Hasil output SPSS (23.0), 2019

Reliabilitas dikatakan baik apabila besar alpha mendekati nilai1, yang membuat item-item pernyataan dalam penelitian dapat diandalkan. Hasil penelitian reliabilitas dari variabel bebas maupun variabel terikat dalam penelitian ini menunjukkan koefisien yang lebih besar dari 0.60 sehingga dapat disimpulkan variabel bebas maupun varibel terikat sudah reliabel.

\subsubsection{Uji Normalitas}

Uji Normalitas bertujuan untuk menguji apakah dalam model regresi, variabel terikat, variabel bebas atau keduanya memiliki distribusi normal atau tidak. Model regresi yang baik adalah yang memiliki distribusi data normal atau yang mendekati normal. Pengujian normalitas data dalam penelitian ini dilakukan dengan menggunakan statistic Kolmogorov-Smirnov atau K-S dengan bantuan program SPSS (Statistic Package of Social Science) for Windows versi 23.0.

Caranya adalah dengan membandingkan distribusi kumulatif relatif teoritisnya (harapannya) atau Fcr(x). Kesimpulanya dengan melihat Sig (2-tailed), apabila Sig(2-tailed) lebih besar dari level of significant yang dipakai (5\% atau 0.05 ), maka data atau residual yang dianalisis berdistribusi normal (Ghozali, 2016:114).

Tabel 14. Hasil Uji Normalitas 
One-Sample Kolmogorov-Smirnov Test

\begin{tabular}{|ll|r|}
\hline & & Unstandardized Residual \\
\hline Normal Parameters & & 112 \\
& & \\
& Mean & .0000000 \\
Most Extreme Differences & Std. Deviation & 1.89464721 \\
& Absolute & .093 \\
& Positive & .054 \\
Kolmogorov-Smirnov Z & Negative & -.093 \\
Asymp. Sig. (2-tailed) & & .982 \\
\end{tabular}

Sumber : Hasil output SPSS (23.0), 2019

Hasil uji normalitas Kolmogorov-Smirnov Test menunjukkan bahwa berdasarkan nilai Sig (2-tailed), dapat dilihat bahwa sig (2-tailed) $(0,290)>$ dari level of significant $(0,05)$, sehingga dapat disimpulkan bahwa variabel motivasi kerja terhadap produktivitas normal.

\subsubsection{Analisis Regresi Sederhana}

Tabel 15. Hasil Analisis Regresi Linear Sederhana

\begin{tabular}{|c|c|c|c|c|c|c|}
\hline \multicolumn{7}{|c|}{ Coefficients $^{a}$} \\
\hline \multirow[b]{2}{*}{ Model } & & \multicolumn{2}{|c|}{ Unstandardized Coefficients } & $\begin{array}{l}\text { Standardized } \\
\text { Coefficients }\end{array}$ & \multirow[b]{2}{*}{$\mathrm{t}$} & \multirow[b]{2}{*}{ Sig. } \\
\hline & & B & Std. Error & Beta & & \\
\hline 1 & (Constant) & 10.046 & .808 & & 12.430 & .000 \\
\hline & $\mathrm{x}$ & .356 & .037 & 679 & 9.688 & 000 \\
\hline
\end{tabular}

Sumber : Hasil output SPSS (23.0), 2019

Berdasarkan Tabel 15 dapat dijelaskan bahwa hasil analisis regresi linear sederhana dapat ditulis persamaan regresi yaitu : $\mathrm{Y}=10,046+0,356 \mathrm{X}$. besarnya nilai konstanta sebesar 10,046 mempunyai makna bahwa apabila variabel motivasi kerja tidak mengalami perubahan atau sama dengan konstan maka produktivitas karyawan sebesar 10,046.

Nilai koefisien regresi variabel motivasi kerja sebesar 0,356 artinya bahwa apabila motivasi kerja meningkat satu satuan, maka produktivitas karyawan juga mengalami peningkatan sebesar satu satuan.

\subsubsection{Hasil Uji Hipotetsis (Uji $\mathbf{t}_{\text {test) }}$}

Pengujian yang dilakukan secara parsial terhadap parameter dilakukan dengan menggunakan uji t-test. Pengujian ini dilakukan untuk mengetahui signifikansi perbedaan 2 buah mean yang berasal dari 2 buah distribusi atau menguji secara parsial masing-masing setiap variabel dengan membandingkan nilai $\mathrm{t}_{\text {hitung }}$ dengan $\mathrm{t}_{\text {tabel }}$. Dasar pemikiran $\mathrm{Uji}$ t dalam penelitian ini, yakni :

$\mathrm{Ha}=$ Ada pengaruh positif dan signifikan antara motivasi kerja $(\mathrm{X})$ terhadap produktivitas karyawan (Y).

$\mathrm{H}_{0}=$ Tidak ada pengaruh yang positif dan signifikan antara motivasi kerja (X) terhadap produktivitas karyawan (Y).

Hasil Uji t dapat dilihat sebagai berikut. 
Tabel 16. Hasil Ujit

\begin{tabular}{|c|c|c|c|c|c|c|}
\hline \multicolumn{7}{|c|}{ Coefficients $^{\mathrm{a}}$} \\
\hline \multirow{2}{*}{\multicolumn{2}{|c|}{ Model }} & \multicolumn{2}{|c|}{ Unstandardized Coefficients } & \multirow{2}{*}{\begin{tabular}{c|}
$\begin{array}{c}\text { Standardized } \\
\text { Coefficients }\end{array}$ \\
Beta \\
\end{tabular}} & \multirow[b]{2}{*}{$\mathrm{T}$} & \multirow[b]{2}{*}{ Sig. } \\
\hline & & B & Std. Error & & & \\
\hline 1 & (Constant) & 10.046 & .808 & & 12.430 & .000 \\
\hline & $x$ & .356 & .037 & .679 & 9.688 & .000 \\
\hline
\end{tabular}

Sumber : Hasil output SPSS (23.0), 2019

Berdasarkan Tabel 16 dapat dilihat bahwa hasil Uji t dalam penelitian ini variabel bebas memiliki taraf signifikansi motivasi kerja (X) sebesar 0,000. Pengaruh nyata motivasi kerja terhadap produktivitas karyawan diuji dengan distribusi t dengan menggunakan level of significant $5 \%$, serta degree of freedom $(d f)=112-1-1=110$.

Keterangan :

$\alpha=$ signifikansi $=0,05$

$\mathrm{n}=$ Jumlah responden

$\mathrm{K}=$ Jumlah variabel bebas

Sehingga mendapatkan hasil :

$\mathrm{t}_{\text {tabel }}=(0,05 / 2 ; 112-1-1) \mathrm{t}_{\text {tabel }}=(0,025 ; 110)$

Adapun kriteria penerimaan/penolakan hipotesis yang telah dirumuskan terkait pengaruh variabel bebas terhadap variabel terikat adalah :

1) Jika t-hitung $\leq \mathrm{t}_{\text {-tabel }}$ dan nilai sig. $>$ alpha $2,5 \%(0,025)$ maka $\mathrm{H}_{0}$ diterima, dan Ha ditolak

2) Jika t-hitung $>\mathrm{t}$-tabel dan nilai sig. $<$ alpha $2,5 \%(0,025)$ maka $\mathrm{H}_{0}$ ditolak dan Ha diterima

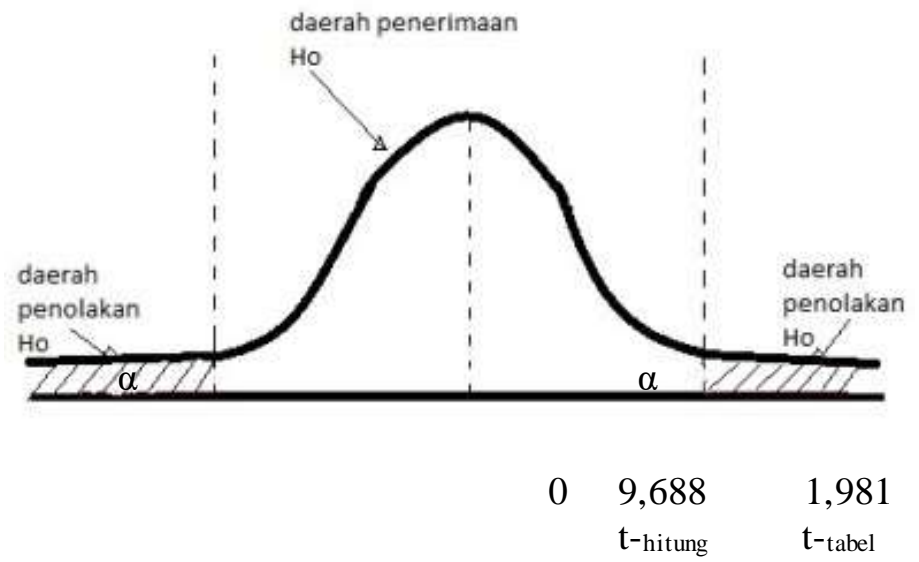

Ga mbar 1. Kurva Distribusi Ujit Pengaruh Motivasi Kerja (X) terhadap Produktivitas Karyawan (Y)

(Sumber : Hasil Penelitian, 2019)

\subsubsection{Koefisien Determinasi}

Koefisien determinasi digunakan untuk mengetahui seberapa besar persentase dari pengaruh variabel independe terhadap variabel dependen, yang dirumuskan dengan :

$\mathrm{D}=\mathrm{R}^{2} \times 100 \%$ Yaitu : $\quad \mathrm{D}:$ Determinasi

$\mathrm{R}$ : Koefisien Korelasi

Yang dapat diartikan bahwa hasil dari $\mathrm{R}^{2}$ merupakan hasil dari seberapa persen variabel bebas memberikan pengaruh terhadap variabel terikat. 
Tabel 17 Hasil Uji Koefisien Determinasi

Sumber : Hasil output SPSS (23.0), 2019

Model Summary ${ }^{\mathrm{b}}$

\begin{tabular}{|l|r|r|r|r|}
\hline Model & R & \multicolumn{1}{|c|}{ R Square } & Adjusted R Square & Std. Error of the Estimate \\
\hline 1 & .679 & .460 & .455 & 1.90324 \\
\hline
\end{tabular}

Berdasarkan pada Tabel 17 dapat dilihat bahwa nilai $\mathrm{R}^{2}$ sebesar 0,460 , yang berarti sebesar $46 \%$ variabel motivasi kerja, sedangkan 0,54 lainnya dipengaruhi faktor lain yang tidak dijabarkan dalam penelitian ini. Adapun variabel yang tidak dijabarkan dalam penelitian ini antara lain disiplin kerja, pendidikan, sikap dan etika, tingkat penghasilan, lingkungan kerja dan iklim kerja.

\subsection{Pembahasan Hasil Pengujian Hipotesis}

Berdasarkan pada hasil uji t dapat dilihat signifikansi pada variabel motivasi kerja (X) menunjukkan nilai sig lebih kecil dari 0,025 maka dapat disimpulkan bahwa, motivasi kerja berpengaruh positif dan signifikan terhadap produktivitas karyawan (Y). Berdasarkan hasil uji dalam penelitian ini, menunjukan bahwa motivasi kerja berpengaruh signifikan terhadap produktivitas karyawan. Berdasarkan pada persepsi karyawan yang berjumlah 112 orang terhadap variabel motivasi kerja $(\mathrm{X})$ dapat dilihat bahwa karyawan memberikan nilai tertinggi pada indikator Anda termotivasi untuk mendapatkan promosi jabatan karena adanya tambahan pembayaran upah $(2,78)$. Sehingga dapat ditafsirkan dengan adanya promosi jabatan karyawan akan lebih termotivasi untuk lebih meningkatkan produktivitasnya kerjanya.

Adapun karyawan memberikan skor terendah berada pada indikator Anda termotivasi dengan pekerjaan karena mendapatkan penghargaan dengan rata-rata nilai 2,57, meski indikator tersebut masih berada pada penilaian setuju (Interval 2,22-2,82). Hal ini menunjukan beberapa karyawan beranggapan bahwa pemberian penghargaan tidak menjadi motivasi kerja untuk meningkatkan produktivitas.

Hasil penelitian ini didukung oleh penelitian yang dilakukan oleh Prasetyo dan Wahyuddin (2003) menyatakan bahwa variabel motivasi kerja berpengaruh positif terhadap produktivitas karyawan Riyadi Palace Hotel di Surakarta. Hasil penelitian ini juga mendukung penelitian yang dilakukan Tjandara dan Setiawati (2014) menyatakan bahwa variabel motivasi memiliki pengaruh postif signifikan terhadap kepuasan kerja karyawan food and beverage " $X$ " Hotel Surabaya.

\section{KESIMPULAN}

Berdasarkan hasil dan pembahasan yang telah dipaparkan mengenai motivasi kerja dan produktivitas karyawan di Komaneka Resorts, Komaneka Bisma Ubud yang telah dibahas di atas maka dapat disimpulkan bahwa: 1) Variabel Motivasi Kerja (X) menunjukan pengaruh yang positif dan signifikan terhadap variabel produktivitas karyawan (Y) di Komaneka Resorts Komaneka Bisma Ubud, 2) Motivasi kerja memberikan pengaruh sebesar $46 \%$ terhadap produktivitas karyawan di Komaneka Bisma Ubud.

\section{Ucapan Terima kasih}

Penulis mengucapkan terima kasih kepada pihak-pihak yang sudah terlibat dalam penuliasan laporan ini diantaranya Universitas Udayana tempat penulis menempuh pendidikan. Juga kepada Dr. Drs. I Nyoman Sunarta, M.Si. Selaku Dekan Fakultas Pariwisata, Dra. Anak Agung Putri Sri, M.Si. Selaku Koordinator Program Studi Diploma IV Pariwisata, Fakultas Pariwisata, Universitas Udayana, Ibu Ni Made Ariani, SE. M.Par. selaku pembimbing akademik yang telah membimbing selama proses perkuliahan, Dra. Anak Agung Putri Sri, M.Si selaku dosen pembimbing I Laporan Tugas Akhir yang telah membimbing, memberikan saran dan masukan bagi laporan ini, Dr. Ni Putu Ratna Sari S.ST.Par. M.Par. selaku dosen pembimbing II Laporan Tugas 
Akhir yang juga telah membimbing, memberikan saran dan masukan bagi laporan ini dan seluruh dosen Fakultas Pariwisata Universitas Udayana yang tidak dapat penulis sebutkan satu-persatu, yang telah mendidik dan memberikan ilmunya kepada penulis. Selanjutnya penulis mengucapkan terima kasih kepada manajemen dan karyawan operasional Komaneka Resorts, Komaneka Bisma Ubud yang telah memberikan izin, informasi dan data pada penelitian ini.

\section{DAFTAR PUSTAKA}

Agustin, R.P. 2014. Hubungan Antara Produktivitas KErja Terhadap Pengembangan Karir Pada Karyawan PT. Bank Mandiri Tarakan. E-Journal Psikologi. Vol 02(01). Pp22-40. (Diakses 8 Agustus 2019)

Ali, F. Omar, R \& Amin, M.2013. An Exomination Of The Relationship Between Physical Environment, Perceived Value, Image \& Behavioural Intentions : A SEM Aproach Towards Malaysian Resort Hotel. Journal of Hotel \& Tourism Management. Vol 27(2). pp 9-26.

(Diakses 8 Agustus 2019).

Cascio, Wayne F. 2013. Managing Human Resources. New York : The McGraw-Hill Companies

Cetin, Ibrahim. 2016. Motivation And Its Impact On Labour Productivity At Hotel Business "A Conceptual Study". International Journal Of New Trends In Arts, Sport \& Science Education, European Unversity of Lefke. Vol 2(1). pp 70-79. ISSN: 2146-9466. (Diakses pada tanggal 7 Agustus 2019).

Edi, Sutrisno. 2016. Manajemen Sumber Daya Manusia. Jakarta: Kencana.

Edyun, Neti. 2012. Hubungan Antara Stres Kerja Dengan Produktivitas Kerja Karyawan. Yogyakarta:Pustaka Pelajar.

Febri Ananta, I Ketut. 2016. Pengaruh Disisplin Kerja Karyawan Dan Budaya Organisasi Terhadap Produktivitas Kerja Karyawan Pada Villa Mahapala Sanur-Denpasar. E-Journal Manajemen Universitas Udayana. Vol 5(2). ISSN: 2302-8912. (Diakses 7 Agustus 2019).

Ghozali, Imam. 2016. Aplikasi Analisis Multivariete Dengan Program IBM SPSS 23, Edisi ke VIII. Semarang : Badan Penerbit Universitas Diponegoro.

Hasibuan, Malayu S.P. 2003. Manajemen Sumber Daya Manusia Edisi Revisi. Jakarta : Bumi Aksara. . 2012. Manajemen Sumber Daya Manusia. Jakarta : PT Bumi Aksara

International Labour Organization. 2014. Safety And Health At Work : A Vision For sustainable Prevention. Germany : ILO.

Kahsay, Haftamu. 2018. Determinant Of Employees' Motivation In The Hotels Industry. African Journal of Marketing and Consumer Research, Department of Marketing Management College of Business and Economic, Mekelle University, Mekelle Ethiopia. Vol 43(7). ISSN : 2422-8451. (Diakses 11 Agustus 2019).

Mangkunegara, A.A Anwar Prabu. 2013. Manajemen Sumber Daya Manusia Perusahaan. Bandung : Remaja Rosdakarya. 
Mondy, R Wayne \& Robert, M. Noe. 2015. Human Resource Management, Ninth Edition. US A : Prentice Hall.

Samsudin, Sadili. 2010. Manajemen Sumber Daya Manusia. Bandung: Pustaka Setia.

Sedarmayanti. 2009. Sumber Daya Manusia Dan Produktivitas Kerja. Bandung:CV Mandar Maju.

Siagian, Sondang P. 2014. Manajemen Sumber Daya Manusia. Jakarta:Bumi Aksara.

Sikula, Andrew F. 1976. Personel Administration And Human Resources Management. New York:John Wiley \& Sons.

Sugiyono. 2017. Metode Penelitian Kuantitatif KualitatifDan R\&D. Bandung : Alfabeta.

Sulistiyani, Ambar Teguh. 2003. Manajemen Dan Sumber Daya Manusia : Konsep Teori Dan Pengembangan Dalam Konteks Organisasi Publik. Yogyakarta:Graha Ilmu.

Sunyoto, Danang. 2013. Teori, Kuesioner Dan Analisis Data Sumber Daya Manusia Dalam Organisasi Sekolah. Yogykarta:Multi Presindo.

Undang-Undang Nomor 10 Tahun 2009

Wexley \& Yukl. 2012. Perilaku Organisasi Dan Psikologi Personalia. Jakarta:Rineka. 